\title{
Morbilliviral infection in a pygmy sperm whale (Kogia breviceps) from Taiwanese waters
}

\author{
Wei-Cheng Yang ${ }^{a, *}$, Victor Fei Pang ${ }^{\text {, }}$ Chian-Ren Jeng ${ }^{\text {a }}$ \\ Lien-Siang Chou ${ }^{b}$, Ling-Ling Chueh ${ }^{\mathrm{a}}$ \\ ${ }^{a}$ Graduate Institute of Veterinary Medicine, National Taiwan University, Taipei 106, Taiwan, ROC \\ ${ }^{\mathrm{b}}$ Graduate Institute of Ecology and Evolutionary Biology, National Taiwan University, Taipei 106, Taiwan, ROC
}

Received 23 September 2005; received in revised form 23 March 2006; accepted 28 March 2006

\begin{abstract}
Morbilliviral infection was diagnosed in an adult male pygmy sperm whale (Kogia breviceps) from southwestern Taiwan on the basis of pathological findings, immunohistochemical staining, and reverse transcription-polymerase chain reaction. The whale was found alive stranded on the beach and died after 5 days of medical care. It was thin and had dozens of nematode in the first stomach. The lungs were dark red and heavy. Histopathological examination revealed diffuse, moderate bronchointerstitial pneumonia. Intranuclear and intracytoplasmic inclusions with occasional syncytial cell formation were noted in the lungs, lymph nodes, and spleen. The RNA extracted from lung tissue was subjected to morbilliviral gene amplification. After priming with specific oligonucleotides, the cDNA covering the phosphoprotein $(\mathrm{P})$ gene was copied and then amplified by PCR. The gene fragment amplified from the lung tissue was sequenced. Phylogenetic analysis of partial P gene revealed $97.6 \%$ sequence identity to the dolphin morbillivirus and $90.2 \%$ similarity to the pilot whale morbillivirus. Morbilliviral antigens were detected in the lungs, lymph nodes, and spleen by immunohistochemistry using polyclonal antibody against rinderpest virus. This is the first report of morbilliviral infection with genetic evidence in a pygmy sperm whale from the Western Pacific Ocean around Taiwan.
\end{abstract}

(C) 2006 Elsevier B.V. All rights reserved.

Keywords: Cetacean morbillivirus; Taiwanese waters; Pygmy sperm whale; Kogia breviceps

\footnotetext{
* Present address: Graduate Institute of Ecology and Evolutionary Biology, College of Life Science, National Taiwan University, No. 1, Sec. 4, Roosevelt Rd., Taipei 106, Taiwan. Tel.: +886 2 33662468; fax: +886223639902.

E-mail address: jack0912@yahoo.com (W.-C. Yang).
}

\section{Introduction}

Morbilliviral infections were reported to occur epizootically in striped dolphins (Stenella coeruleoalba), Atlantic bottlenose dolphins (Tursiops truncatus), and common dolphins (Delphinus delphis ponticus) from different oceans of the world (Van Bressem et al., 2001). Morbilliviruses have also caused diseases in European harbor porpoises 
(Phocoena phocoena) (Kennedy et al., 1988), a Pacific white-sided dolphin (Lagenorhynchus obliquidens) (Uchida et al., 1999), pilot whales (Globicephala melas and G. macrorhynchus) from the Western North Atlantic (Duignan et al., 1995; Taubenberger et al., 2000), and fin whales (Balaenoptera physalus) from Belgium (Jauniaux et al., 2000).

Most dolphins with morbilliviral diseases beached dead or stranded in a dying phase. Majority of the affected animals presented with serious secondary bacterial and fungal infections due to the immuosuppressive nature of the virus (Birkun et al., 1999). Characteristic lesions included interstitial pneumonia, lymphoid depletion, and formation of eosinophilic intranuclear and intracytoplasmic inclusion bodies and syncytial cells in some affected tissues (Schulman et al., 1997).

Several serological studies have suggested that the viruses infecting several species of Delphinidae in the Pacific Ocean were closely related, or identical, to the cetacean morbillivirus presented in the North Atlantic and the Mediterranean Sea (Van Bressem et al., 1998, 2001). To date, there has been only one report of morbilliviral infection so far in a Pacific white-sided dolphin (Lagenorhynchus obliquidens) in the Western Pacific Ocean around Japan (Uchida et al., 1999). Here, we report a case of serious morbilliviral infection in a pygmy sperm whale (Kogia breviceps) from Taiwan.

\section{Materials and methods}

\subsection{Necropsy and sampling}

A thorough necropsy was carried out immediately after the whale died. Samples of the lungs, trachea, lung-associated lymph nodes, heart, prescapular lymph node, liver, spleen, stomach, intestine, jejunal lymph node, kidney, urinary bladder, and adrenal gland were frozen at $-70{ }^{\circ} \mathrm{C}$ or fixed in $10 \%$ neutral buffered formalin until used. Sections at $5 \mu \mathrm{m}$ from formalin-fixed and paraffin-embedded various tissues were stained with hematoxylin and eosin for light microscopic examination.

\subsection{Immunohistochemistry}

Formalin-fixed and paraffin-embedded tissue sections at $5 \mu \mathrm{m}$ were stained immunohistochemically using the avidin-biotin complex immunoperoxidase method (VECTASTAIN ${ }^{\circledR}$ Universal Quick Kit, Vector Labs, Burlingame, CA, USA). A rabbit polyclonal antiserum to rinderpest virus (kindly provided by Dr. T. Barrett, Institute for Animal Health, UK) was used as the primary antibody. Briefly, serial sections of each tissue block were incubated with 1:4000 and 1:8000 dilutions of the rinderpest antiserum and an additional serial section was incubated with an irrelevant rabbit antiserum diluted 1:4000. Positive control sections from the brain of a dog infected with canine distemper virus were tested concurrently. Diaminobenzidine chromagen (DAB) (Sigma Chemical Co., St. Louis, MO, USA) was used as the substrate to produce a dark brown precipitate. The sections were then counterstained with hematoxylin.

\subsection{Reverse transcription-polymerase chain reaction $(R T-P C R)$ and sequence analysis}

Frozen samples of lung tissue were used for RNA extraction and subsequent RT-PCR according to the method described by Krafft et al. (1995) with modifications. Briefly, 50-100 mg of lung tissue were homogenized in TRIZOL Reagent (Invitrogen, Carlsbad, CA, USA) followed by chloroform extraction. The RNA in aqueous phase was precipitated. Primers P1 (5'-ATTGGGTTGCACCACTTGTC- $\left.3^{\prime}\right)$ and P2 $\left(5^{\prime}\right.$-ATGTTTATGATCACAGCGGT- $\left.3^{\prime}\right)$ recognizing the phosphoprotein $(\mathrm{P})$ gene and yielding a $429 \mathrm{bp}$ product (Barrett et al., 1993) were used for first strand cDNA synthesis and PCR amplification. The RNA was reversely transcribed with murine reverse transcriptase (RT-PCR Core Kit, Perkin-Elmer, Applied Biosystems, Foster City, CA, USA) and the resulting cDNA served as a template for PCR following the manufacturer's protocol. A PCR reaction mixture, containing 50 pmol primer pairs, $1.25 \mathrm{U}$ PfuTurbo DNA polymerase (Stratagene, La Jolla, CA, USA), and $5 \mu \mathrm{l}$ of 10 -fold concentrated PCR buffer, was added to each tube. Amplification was carried out in a thermal cycler (DNA Thermal Cycler 480, PerkinElmer) under the following conditions: $94{ }^{\circ} \mathrm{C}$ for $120 \mathrm{~s} ; 40$ cycles of $94{ }^{\circ} \mathrm{C}$ for $60 \mathrm{~s}, 55^{\circ} \mathrm{C}$ for $60 \mathrm{~s}$, and $72{ }^{\circ} \mathrm{C}$ for $30 \mathrm{~s}$ each; followed by a final extension of $72{ }^{\circ} \mathrm{C}$ for $420 \mathrm{~s}$. The products were then analyzed by gel electrophoresis on $2 \%$ agarose gels and visualized 
by ethidium bromide staining. $\beta$-Actin was used as the internal control. Bands representing PCR products within the expected size range were excised from the gel extracted and purified using a commercialized nucleic-acid-binding resin (Qiaex II Gel extraction kit; QIAGEN, Valencia, CA, USA). The nucleotide sequences of the extracts were determined by dideoxy nucleotide methodology using an automated sequencer (Model 373; Applied Biosystems). The nucleotide sequences of the amplicons were compared to the known morbilliviruses using the DNAStar software program (DNASTAR Inc., Madison, WI, USA).

\section{Results}

\subsection{Biological, clinical and pathological findings}

A male pygmy sperm whale (KH9901), $325 \mathrm{~cm}$ in length and $350 \mathrm{~kg}$ in weight, was found stranded alive on the coast of Kaohsiung City in southwestern
Taiwan. The whale was very thin as shown by a prominent neck, reduced blubber, and severe atrophy of the dorsal muscles. There were several recent cookie-cutter shark bites on the abdomen. Areas of skin loss were noted at the leading edges of the fins, flippers, and flukes. Core temperature was $39^{\circ} \mathrm{C}$. A large amount of brown to dark red, foul, mucopurulent discharge exuded from the blowhole. The whale was transported to a nearby rescue pool in Chyi-Jihn Aquarium. Blowhole culture performed on the second day isolated Aeromonas hydrophila and A. caviae. The whale died after 5 days of medical care which included injecting antibiotics (amikacin and enrofloxacin) and tube-feeding. Upon necropsy, it was found that the lungs were dark red and heavy. A plastic rope, a plastic bag, and dozens of nematodes were found in the first stomach. Sexual maturity was confirmed from the measurement of testis $(43 \mathrm{~cm} \times 10 \mathrm{~cm} \times 10 \mathrm{~cm}$ in dimensions). Histopathological examination revealed diffuse, moderate bronchointerstitial pneumonia (Fig. 1a). The alveolar septa were variably thickened

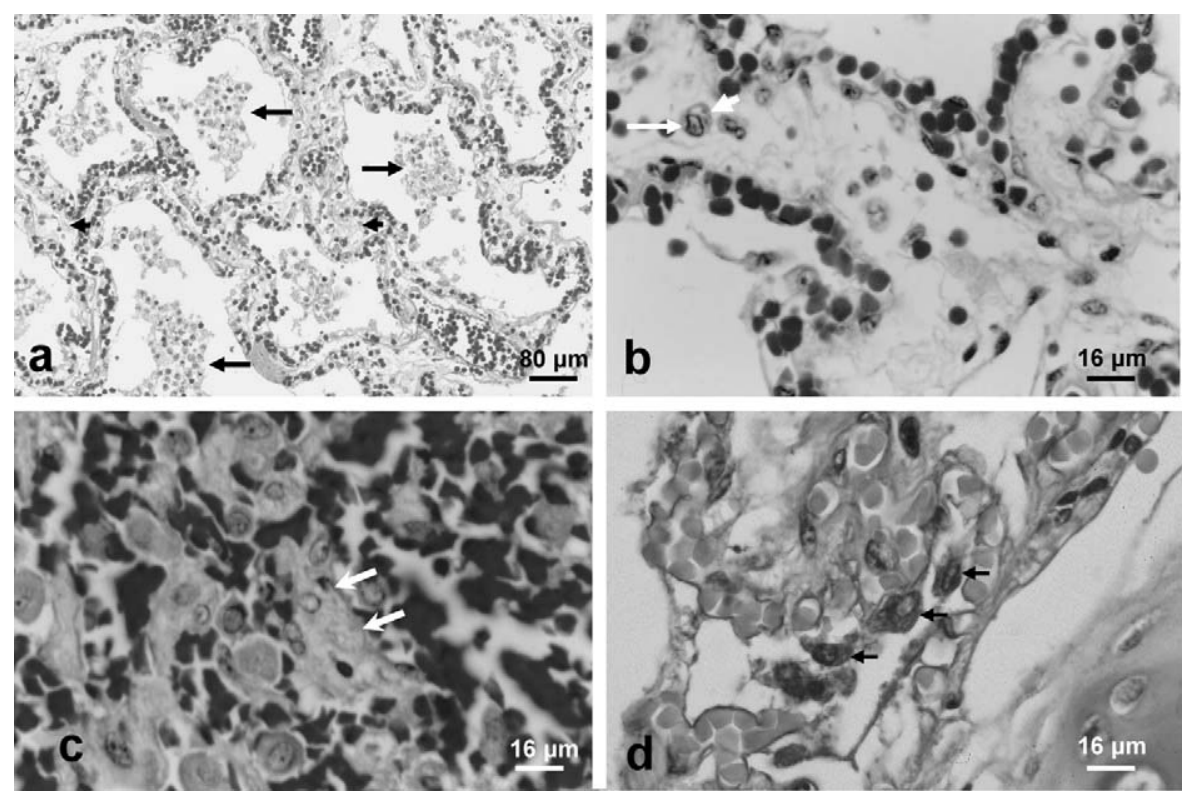

Fig. 1. Pygmy sperm whale (K. breviceps): cetacean morbillvirus infection (lung and lymph node). (a) Moderate diffuse pneumonia is characterized by thickening of the epithelium caused by edema (arrowheads), prominent mononuclear inflammatory cell infiltration (arrows), and fibrin deposition in the alveolar spaces. Hematoxylin-eosin (HE) stain. (b) Margination of chromatin and formation of intranuclear (arrow) and intracytoplasmic (arrowhead) inclusions are observed in a macrophage present in the edematous alveolar septum. HE stain. (c) A syncytial cell (arrowhead) is observed in the cortex of the lung-associated lymph node. HE stain. (d) Intense immunostaining for morbilliviral antigen (arrows) is observed in the alveolar epithelial cells and mononuclear inflammatory cells.Immunoperoxidase technique with a polyclonal antibody against rinderpest virus as primary antibody. Hematoxylin counterstain. 
by edema, fibrin deposition, infiltration of mononuclear inflammatory cells, and hyperplasia of type II pneumocytes. There were large numbers of mononuclear inflammatory cells mixed with some fibrin and cell debris in the bronchioli and alveolar spaces. Occasionally, eosinophilic, intranuclear and/or intracytoplasmic inclusions were seen in the alveolar macrophages (Fig. 1b) and epithelial cells. Lymph nodes showed prominent macrophage infiltration, mild lymphoid depletion, scattered syncytial cells (Fig. 1c), and formation of similar intranuclear and/or intracytoplasmic inclusion bodies in some macrophages. Immunohistochemical staining with a rabbit anti-rinderpest virus hyperimmune serum revealed positive cells in the lungs, lymph nodes, and spleen. In the lungs, the positive signals were found in

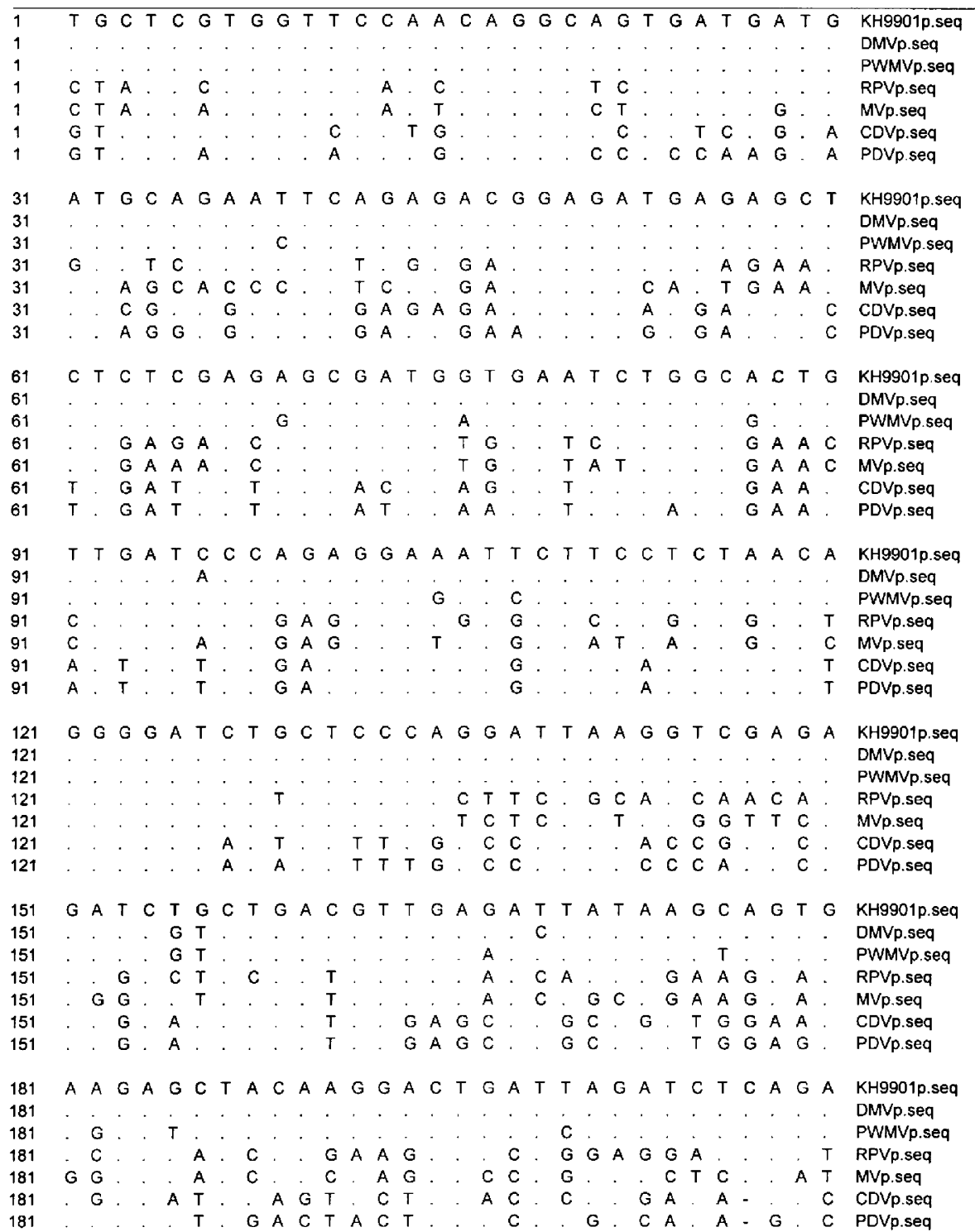

Fig. 2. Sequence alignment based on the phosphoprotein $(\mathrm{P})$ gene of various known morbilliviruses, including the morbillivirus from the pygmy sperm whale in this study (KH9901), dolphin morbillivirus (DMV), pilot whale morbillivirus (PWMV), rinderpest virus (RPV), measles virus (MV), canine distemper virus (CDV), and phocine distemper virus (PDV), using Clustal method with weighted residue weight table. 


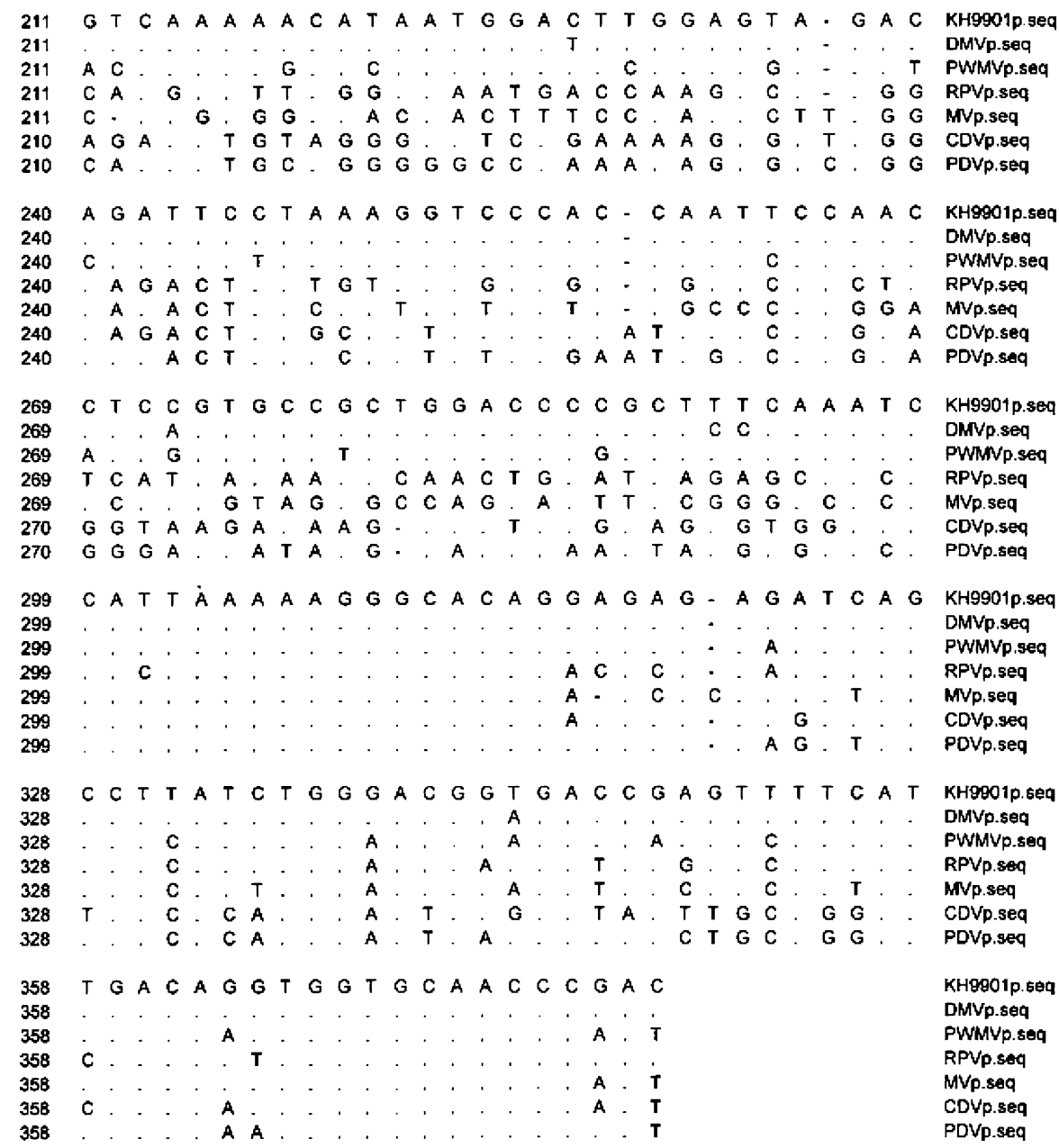

Fig. 2. (Continued).

the alveolar epithelial cells and macrophages (Fig. 1d). The positive signals were also seen in the lymphocytes and macrophages in the lymph nodes and spleen.

\subsection{RT-PCR and sequence analysis}

After amplification of the P gene, a 429 bp DNA product was detected (data not shown). Partial $\mathrm{P}$ gene nucleotide sequence of $403 \mathrm{bp}$ (Genbank accession no. AF333347) was determined and the sequence was aligned with those published $\mathrm{P}$ gene sequences of dolphin morbillivirus (DMV, Genbank accession no. AJ608288), pilot whale morbillivirus (PWMV, Genbank accession no. AF200817), measles virus (MV,
Genbank accession no. M10456), rinderpest virus (RPV, Genbank accession no. AB021977), phocine distemper virus (PDV, Genbank accession no. X75960), and canine distemper virus (CDV, Genbank accession no. AF181446) (Fig. 2). Computer analysis using the DNASTAR program generated the sequence pair distances and phylogenetic tree showing the relationships among the various morbillivirus species and our sequence is shown in Fig. 3. The sequence from the present case (KH9901) is more closely related to DMV and PWMV with 97.6 and $90.2 \%$ sequence identity, respectively, and forms a quite separate group within the morbilliviruses which is closer to the RPV/MV group than to the CDV/PDV group. 


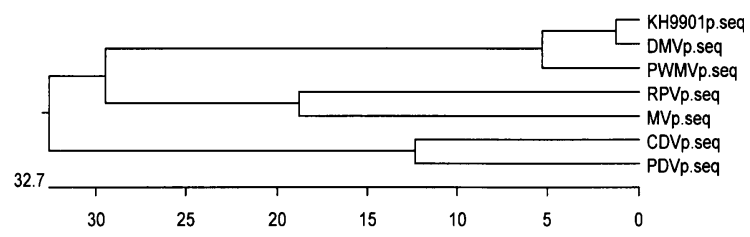

Fig. 3. Phylogenetic tree based on the $\mathrm{P}$ gene region of various known morbilliviruses, including the morbillivirus from the pygmy sperm whale in this study (KH9901), dolphin morbillivirus (DMV), pilot whale morbillivirus (PWMV), rinderpest virus (RPV), measles virus (MV), canine distemper virus (CDV), and phocine distemper virus (PDV), using Clustal method with weighted residue weight table.

\section{Discussion}

The first report of morbilliviral infection in the Western Pacific was from a Pacific white-sided dolphin from Japan with non-purulent meningoencephalomyelitis and a number of CDV-nucleoproteinpositive granular deposits in the cytoplasm and cell processes of the degenerating or intact neurons (Uchida et al., 1999). However, no molecular genetic evidence was shown in that case. Van Bressem et al. (2001) reported a bottlenose dolphin (T. aduncus), caught from Taiwan in 1978 and kept in Hong Kong Ocean Park since then, had high serum antibody titers against DMV in 1994 and 1999, respectively. They supposed that the dolphin may have been infected in the wild before 1978 because there was no evidence supporting captivity-acquired infection if morbilliviruses could induce long-lasting humoral immunity as suggested (Black, 1991). In this study, we provide pathological, immunohistochemical and molecular genetic evidence of serious morbilliviral infection in a pygmy sperm whale from Taiwanese waters. With all of the above cases, we suppose that a morbillivirus has circulated for decades among cetaceans inhabiting the waters of Taiwan and neighboring area. However, it is not clear whether the existence of morbillivirus in the Northwestern Pacific Ocean affects noticeably the health of cetaceans living in this region. Morbilliviruses generally cause heavy mortalities when introduced in a naive population, as observed during the morbillivirus epizootics in striped and bottlenose dolphins in the Mediterranean Sea and Northwestern Atlantic, respectively (Lipscomb et al., 1994, 1996; Van Bressem et al., 1991). Comparatively speaking, there was no unusual non-fishery related mortalities of cetaceans along the Taiwan coasts in the period since 1991 (Chou et al., 2005) and only a few cases mentioned above were reported, suggesting a morbillivirus is either enzootic or is being re-introduced frequently in cetaceans in the Northwestern Pacific Ocean. Nevertheless, a serological survey for cetaceans inhabiting in this areas will be needed to reveal the exact infection status.

Several studies indicated that trace metal and polychlorinated biphenyls (PCB) exposure might influence the health status of marine mammals and thus contributed to the high mortality rates in the past decade (Aguilar and Borrell, 1994; Das et al., 2004; Jepson et al., 1999; Lahvis et al., 1995; Ross et al., 1996; Troisi et al., 2001). The immune resistance of the animals may be reduced by high levels of organochlorine contaminants which likely contribute to the severity of morbillivirus outbreaks (Aguilar and Borrell, 1994; Ross et al., 1996). Comparing with the studies mentioned above, cetaceans from Taiwanese waters had a relatively low level of PCB concentration (Chou et al., 2004) and the mercury level did not show any significant elevation either (Chen et al., 2002), suggesting that the health condition of cetaceans living around Taiwan may be less affected by the pollutants. On the basis of the evidence, we hypothesize that morbilliviral infection in cetaceans from Taiwan and adjacent area may cause low mortality, as shown by a few reported cases. However, the assessment of the health condition in cetaceans from this area should be performed continuously for early alert of epidemic outbreak.

Death of thousands of striped dolphins from DMV infection in the Mediterranean Sea was reported (Van Bressem et al., 1993). Unlike striped dolphins which are highly gregarious and occasionally congregate in hundreds (Valsecchi et al., 2004), pygmy sperm whales are not considered sociable as they are usually observed alone or in a small group of up to six (Reeves et al., 2002a). Infectious diseases may spread slowly in the pygmy sperm whale population and epizootics unlikely happen in this species. Similar situation was noted in the porpoise morbillivirus infection of European harbor porpoises (Kennedy et al., 1991) which are generally solitary and are seen alone or in small groups of two to five individuals (Reeves et al., 2002b). These two species are perceived to lose their immunity relatively easily due to their nonsocial 
behavior and re-introduction of morbillivirus may cause infrequent mortality of susceptible animals, which should not impact on the population numbers.

In conclusion, no abnormal mass mortality related to morbillvirus infection has been identified during recent decade in Taiwan. The gross or pathological abnormalities consistent with morbillivirus infection in cetaceans have never been recorded in Taiwan before this report. Our report provided the first evidence of morbillivirus infection in a stranded pygmy sperm whale from the Western Pacific Ocean. A systematical research, including serological, pathological, and epidemiological studies, of morbilliviral diseases in cetaceans is needed to ascertain whether or not morbillivirus circulates in the Northwestern Pacific Ocean and subsequently assess the potential impact on the cetacean populations.

\section{Acknowledgements}

We are grateful to Dr. Thomas Barrett (from Institute for Animal Health, Pirbright Laboratory, UK) for kindly providing rinderpest hyperimmune serum. We also thank the staffs and volunteers of Taiwan Cetacean Society for medical care and necropsy assistance.

\section{References}

Aguilar, A., Borrell, A., 1994. Abnormally high polychlorinated biphenyl levels in striped dolphins (Stenella coeruleoalba) affected by the 1990-1992 Mediterranean epizootic. Sci. Total Environ. 154, 237-247.

Barrett, T., Visser, I.K., Mamaev, L., Goatley, L., van Bressem, M.F., Osterhaust, A.D., 1993. Dolphin and porpoise morbilliviruses are genetically distinct from phocine distemper virus. Virology 193, 1010-1012.

Birkun Jr., A., Kuiken, T., Krivokhizhin, S., Haines, D.M., Osterhaus, A.D., van de Bildt, M.W., Joiris, C.R., Siebert, U., 1999. Epizootic of morbilliviral disease in common dolphins (Delphinus delphis ponticus) from the Black Sea. Vet. Rec. 144, 85-92.

Black, F.L., 1991. Epidemiology of Paramyxoviruses. In: Kingsbury, D.W. (Ed.), The paramyxoviruses (Viruses Series). Plenum Publishing Corporation, New York, pp. 509-536.

Chen, M.H., Shih, C.C., Chou, C.L., Chou, L.S., 2002. Mercury, organic-mercury and selenium in small cetaceans in Taiwanese waters. Mar. Pollut. Bull. 45, 237-245.

Chou, C.C., Chen, Y.N., Li, C.S., 2004. Congener-specific polychlorinated biphenyls in cetaceans from Taiwan waters. Arch. Environ. Contam. Toxicol. 47, 551-560.
Chou, L.S., Huang, M.W., Yang, W.C., 2005. Taiwan cetacean stranding record. In: Proceedings of the Symposium \& Workshop on the Ecology and Conservation of Cetaceans across Taiwan Strait, Taipei, pp. 56-64.

Das, K., Siebert, U., Fontaine, M., Jauniaux, T., Holsbeek, L., Bouquegneau, J.-M., 2004. Ecological and pathological factors related to trace metal concentrations in harbour porpoises Phocoena phocoena from the North Sea and adjacent areas. Mar. Ecol. Prog. Ser. 281, 283-295.

Duignan, P.J., House, C., Geraci, J.R., Duffy, N., Rima, B.K., Walsh, M.T., Early, G., St Aubin, D.J., Sadove, S., Koopman, H., et al., 1995. Morbillivirus infection in cetaceans of the Western Atlantic. Vet. Microbiol. 44, 241-249.

Jauniaux, T., Charlier, G., Desmecht, M., Haelters, J., Jacques, T., Losson, B., Van Gompel, J., Tavernier, J., Coignoul, F., 2000. Pathological findings in two fin whales (Balaenoptera physalus) with evidence of morbillivirus infection. J. Comp. Pathol. 123, 198.

Jepson, P.D., Bennett, P.M., Allchin, C.R., Law, R.J., Kuiken, T., Baker, J.R., Rogan, E., Kirkwood, J.K., 1999. Investigating potential associations between chronic exposure to polychlorinated biphenyls and infectious disease mortality in harbour porpoises from England and Wales. Sci. Total Environ. 243/ 244, 339-348.

Kennedy, S., Smyth, J.A., Cush, P.F., McCullough, S.J., Allan, G.M., McQuaid, S., 1988. Viral distemper now found in porpoises. Nature 336, 21.

Kennedy, S., Smyth, J.A., Cush, P.F., McAliskey, M., McCullough, S.J., Rima, B.K., 1991. Histopathologic and immunocytochemical studies of distemper in harbor porpoises. Vet. Pathol. $28,1-7$.

Krafft, A., Lichy, J.H., Lipscomb, T.P., Klaunberg, B.A., Kennedy, S., Taubenberger, J.K., 1995. Postmortem diagnosis of morbillivirus infection in bottlenose dolphins (Tursiops truncatus) in the Atlantic and Gulf of Mexico epizootics by polymerase chain reaction-based assay. J. Wildl. Dis. 31, 410-415.

Lahvis, G.P., Wells, R.S., Kuehl, D.W., Stewart, J.L., Rhinehart, H.L., Via, C.S., 1995. Decreased lymphocyte responses in freeranging bottlenose dolphins (Tursiops truncatus) are associated with increased concentrations of PCBs and DDT in peripheral blood. Environ. Health Perspect. 103 (Suppl. 4), 67-72.

Lipscomb, T.P., Schulman, F.Y., Moffett, D., Kennedy, S., 1994. Morbilliviral disease in Atlantic bottlenose dolphins (Tursiops truncatus) from the 1987-1988 epizootic. J. Wildl. Dis. 30, 567571.

Lipscomb, T.P., Kennedy, S., Moffett, D., Krafft, A., Klaunberg, B.A., Lichy, J.H., Regan, G.T., Worthy, G.A., Taubenberger, J.K., 1996. Morbilliviral epizootic in bottlenose dolphins of the Gulf of Mexico. J. Vet. Diagn. Invest. 8, 283-290.

Reeves, R.R., Stewart, B.S., Clapham, P.J., Powell, J.A., 2002a. Pygmy and dwarf sperm whales. In: National Audubon Society Guide to Marine Mammals of the World, Chanticleer Press, New York, pp. 244-247.

Reeves, R.R., Stewart, B.S., Clapham, P.J., Powell, J.A., 2002b. Harbor porpoise. In: National Audubon Society Guide to Marine Mammals of the World, Chanticleer Press, New York, pp. 460-463. 
Ross, P., De Swart, R., Addison, R., Van Loveren, H., Vos, J., Osterhaus, A., 1996. Contaminant-induced immunotoxicity in harbour seals: wildlife at risk? Toxicology 112, 157.

Schulman, F.Y., Lipscomb, T.P., Moffett, D., Krafft, A.E., Lichy, J.H., Tsai, M.M., Taubenberger, J.K., Kennedy, S., 1997. Histologic, immunohistochemical, and polymerase chain reaction studies of bottlenose dolphins from the 19871988 United States Atlantic coast epizootic. Vet. Pathol. 34, 288-295.

Taubenberger, J.K., Tsai, M.M., Atkin, T.J., Fanning, T.G., Krafft, A.E., Moeller, R.B., Kodsi, S.E., Mense, M.G., Lipscomb, T.P., 2000. Molecular genetic evidence of a novel morbillivirus in a long-finned pilot whale (Globicephalus melas). Emerg. Infect. Dis. 6, 42-45.

Troisi, G.M., Haraguchi, K., Kaydoo, D.S., Nyman, M., Aguilar, A., Borrell, A., Siebert, U., Mason, C.F., 2001. Bioaccumulation of polychlorinated biphenyls (PCBs) and dichlorodiphenylethane (DDE) methyl sulfones in tissues of seal and dolphin morbillivirus epizootic victims. J. Toxicol. Environ. Health A $62,1-8$.

Uchida, K., Muranaka, M., Horii, Y., Murakami, N., Yamaguchi, R., Tateyama, S., 1999. Non-purulent meningoencephalomyelitis of a Pacific striped dolphin (Lagenorhynchus obliquidens). The first evidence of morbillivirus infection in a dolphin at the Pacific Ocean around Japan. J. Vet. Med. Sci. 61, 159-162.

Valsecchi, E., Amos, W., Raga, J.A., Podest'a, M., Sherwin, W., 2004. The effects of inbreeding on mortality during a morbillivirus outbreak in the Mediterranean striped dolphin (Stenella coeruleoalba). Anim. Conserv. 7, 139-146.

Van Bressem, M.F., Visser, I.K., Van de Bildt, M.W., Teppema, J.S., Raga, J.A., Osterhaus, A.D., 1991. Morbillivirus infection in Mediterranean striped dolphins (Stenella coeruleoalba). Vet. Rec. 129, 471-472.

Van Bressem, M.F., Visser, I.K., De Swart, R.L., Orvell, C., Stanzani, L., Androukaki, E., Siakavara, K., Osterhaus, A.D., 1993. Dolphin morbillivirus infection in different parts of the Mediterranean Sea. Arch. Virol. 129, 235-242.

Van Bressem, M.F., Van Waerebeek, K., Fleming, M., Barrett, T., 1998. Serological evidence of morbillivirus infection in small cetaceans from the Southeast Pacific. Vet. Microbiol. 59, 89-98.

Van Bressem, M., Van Waerebeek, K., Jepson, P.D., Raga, J.A., Duignan, P.J., Nielsen, O., Di Beneditto, A.P., Siciliano, S., Ramos, R., Kant, W., Peddemors, V., Kinoshita, R., Ross, P.S., Lopez-Fernandez, A., Evans, K., Crespo, E., Barrett, T., 2001. An insight into the epidemiology of dolphin morbillivirus worldwide. Vet. Microbiol. 81, 287-304. 